\title{
Tumefactive Inflammatory Lesions in Juvenile Metachromatic Leukodystrophy
}

Neurol Neuroimmunol Neuroinflamm 2021;8:e969. doi:10.1212/NXI.0000000000000969

In the Clinical Scientific Note "Tumefactive inflammatory lesions in juvenile metachromatic leukodystrophy" by Meier et al., ${ }^{1}$ a few of the references to the figure within the Results section were incorrect; they should read as follows:

1. The reference in line 6 should read (figure, $C$ ).

2. The reference in line 11 should read (figure, $\mathrm{E}$ and $\mathrm{F}$ ).

3. The reference in line 12 should read (figure, I and $\mathrm{J}$ ).

4. The reference in line 17 should read (figure, $\mathrm{P}$ ).

The authors regret these errors. Further, the sentence appearing in lines 7 and 8 of the Discussion section should read "The second patient presented at age 5 years with acute leftsided hemiparesis.” The publisher regrets this error.

\section{Reference}

1. Meier K, Gärtner J, Huppke P. Tumefactive inflammatory lesions in juvenile metachromatic leukodystrophy. Neurol Neuroimmunol Neuroinflamm 2021;8:e922. doi:10.1212/NXI.0000000000000922. 


\section{Neurology $^{\odot}$ \\ Neuroimmunology \& Neuroinflammation}

\section{Tumefactive Inflammatory Lesions in Juvenile Metachromatic Leukodystrophy Neurol Neuroimmunol Neuroinflamm 2021;8; \\ DOI 10.1212/NXI.0000000000000969}

This information is current as of February 2, 2021

\section{Updated Information \& Services}

References

Permissions \& Licensing

Reprints including high resolution figures, can be found at: http://nn.neurology.org/content/8/2/e969.full.html

This article cites 1 articles, 0 of which you can access for free at: http://nn.neurology.org/content/8/2/e969.full.html\#\#ref-list-1

Information about reproducing this article in parts (figures,tables) or in its entirety can be found online at:

http://nn.neurology.org/misc/about.xhtml\#permissions

Information about ordering reprints can be found online: http://nn.neurology.org/misc/addir.xhtml\#reprintsus

Neurol Neuroimmunol Neuroinflamm is an official journal of the American Academy of Neurology.

Published since April 2014, it is an open-access, online-only, continuous publication journal. Copyright $(\subseteq$ 2021 American Academy of Neurology. All rights reserved. Online ISSN: 2332-7812.

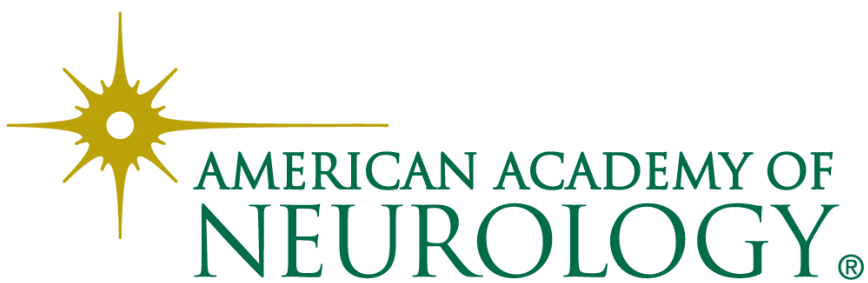

